\title{
Effects of Biofertilizer Produced from Bradyrhizobium and Streptomyces griseoflavus on Plant Growth, Nodulation, Nitrogen Fixation, Nutrient Uptake, and Seed Yield of Mung Bean, Cowpea, and Soybean
}

\author{
Aung Zaw Htwe ${ }^{1,2, * \mathbb{D}}$, Seinn Moh Moh ${ }^{3}$, Khin Myat Soe ${ }^{3}$, Kyi Moe ${ }^{1,2}$ and Takeo Yamakawa ${ }^{4}$ \\ 1 Graduate School of Bioresource and Bioenvironmental Sciences, Faculty of Agriculture, Kyushu University, \\ 744 Motooka, Nishi-ku, Fukuoka 819-0395, Japan; kyimoeyau@gmail.com \\ 2 Department of Agronomy, Yezin Agricultural University, Yezin 15013, Myanmar \\ 3 Department of Agriculture, Ministry of Agriculture, Livestock and Irrigation, Nay Pyi Taw 15011, Myanmar; \\ hanmohmohyau@gmail.com (S.M.M.); khinmyatsoe@gmail.com (K.M.S.) \\ 4 Laboratory of Plant Nutrition, Department of Bioresource and Bioenvironmental Sciences, \\ Faculty of Agriculture, Kyushu University, 744 Motooka, Nishi-ku, Fukuoka 819-0395, Japan; \\ yamakawa@agr.kyushu-u.ac.jp \\ * Correspondence: aungzawhtwe333@gmail.com; Tel.: +81-80-6423-8187
}

Received: 18 January 2019; Accepted: 8 February 2019; Published: 11 February 2019

\begin{abstract}
The use of biofertilizers is important for sustainable agriculture, and the use of nodule bacteria and endophytic actinomycetes is an attractive way to enhance plant growth and yield. This study tested the effects of a biofertilizer produced from Bradyrhizobium strains and Streptomyces griseoflavus on leguminous, cereal, and vegetable crops. Nitrogen fixation was measured using the acetylene reduction assay. Under $\mathrm{N}$-limited or $\mathrm{N}$-supplemented conditions, the biofertilizer significantly promoted the shoot and root growth of mung bean, cowpea, and soybean compared with the control. Therefore, the biofertilizer used in this study was effective in mung bean, cowpea, and soybean regardless of $\mathrm{N}$ application. In this study, significant increments in plant growth, nodulation, nitrogen fixation, nitrogen, phosphorus, and potassium (NPK) uptake, and seed yield were found in mung beans and soybeans. Therefore, Bradyrhizobium japonicum SAY3-7 plus Bradyrhizobium elkanii BLY3-8 and Streptomyces griseoflavus are effective bacteria that can be used together as biofertilizer for the production of economically important leguminous crops, especially soybean and mung bean. The biofertilizer produced from Bradyrhizobium and S. griseoflavus P4 will be useful for both soybean and mung bean production.
\end{abstract}

Keywords: biofertilizer; nitrogen fixation; nodulation; plant growth; seed yield

\section{Introduction}

Leguminous crops are important cash crops, and demand for them for domestic consumption and export is increasing in Myanmar. Currently, around 4.6 billion hectares of pulses are sown annually in all states and regions, and Myanmar leads ASEAN (Association of South East Asain Nations) member countries in pulses production [1]. About one-third of human dietary protein is derived from grain legumes [2]. In addition to their being a rich source of protein, legumes are important because they have the unique ability to produce substantial amounts of organic nitrogen through symbiotic biological nitrogen fixation [3]. Therefore, legume-rhizobia symbiosis can provide an easy, inexpensive way to maintain soil fertility and improve crop production [4].

Leguminous plants can establish symbiosis with bacteria belonging to the genera Rhizobium, Bradyrhizobium, Sinorhizobium, Azorhizobium, Mesorhizobium, and Allorhizobium, collectively known as 
rhizobia [5,6]. Inoculation of the soil with Rhizobium strains increased nodulation, nitrogen acquisition, and legume yield [7]. The process responsible for reducing molecular nitrogen into ammonia is referred as nitrogen fixation [8], and rhizobia play important roles in agriculture, performing biological nitrogen fixation (BNF). BNF is important agronomically because it reduces the need for chemical nitrogen fertilizers [9]. However, the efficiency of the biological process depends on several factors related to the host plant and bacteria, and edaphic factors such as soil acidity, low soil fertility, high temperatures, and drought often limit the contribution of nitrogen fixation [10]. Rhizobium inoculation is very effective at enhancing BFN and crop yields in most legumes, and this practice is adopted by most producers [11].

Nitrogen is important for maintaining and improving crop growth and yield. However, the long-term excessive use of chemical fertilizers in agriculture has unanticipated environmental impacts [12], including soil fertility degradation, soil organic matter deterioration, and decreased water and nutrient holding capacities and nutrient use efficiency $[13,14]$. An alternative to $\mathrm{N}$ fertilizer is effective, efficient rhizobial $\mathrm{N}$-fixing bacteria alone or together. Rhizobium inoculants are relatively inexpensive for leguminous crop production [15]. Therefore, the use of efficient inoculants can be considered an important strategy for sustainable management and reduction of environmental problems by decreasing the use of chemical fertilizers [16].

Plant growth-promoting bacteria (PGPB) enhance plant growth by affecting the availability of nutrients originating from processes such as BNF and phosphate solubilization, alleviating stress through the modulation of 1-aminocyclopropane-1-carboxylate deaminase expression, and producing phytohormones and siderophores [17]. Several commercial PGPB inoculants seem to promote growth through one of three mechanisms: plant disease suppression (bioprotectants), nutrient acquisition improvement (biofertilizers), or phytohormone production (biostimulants) [18]. A biofertilizer is a substance containing living microorganisms that, when applied to seeds, plant surfaces, or soil, colonize the rhizosphere or interior of the plant and promote growth by increasing the supply or availability of nutrients to the host plant [19]. Biofertilizers are important components of integrated nutrient management. Biological fertilizers could potentially play key roles in the productivity and sustainability of soil. Biofertilizers are cost-effective and ecofriendly. The use of biofertilizers improves soil fertility by fixing atmospheric nitrogen, solubilizing insoluble phosphates, producing plant growth-promoting substances in the soil [20], and promoting nodulation ability, which increases yield by $16-60 \%$ [21].

In Myanmar, the Plant Pathology Section of the Department of Agricultural Research (DAR) initiated peat-based inoculant production using exotic strains from NifTAL (Nitrogen Fixation by Tropical Agricultural Legumes) for seven legume crops: groundnut, chickpea, black gram, green gram, soybean, pigeon pea, and cowpea [22]. The use of indigenous rhizobia has been recommended because they adapt easily to environmental conditions, facilitating their survival and successful nodulation by the host plant [23]. However, inoculation is not currently practiced widely in Myanmar [24]. Therefore, this study tested the effects of biofertilizer produced from indigenous Bradyrhizobium strains and Streptomyces griseoflavus on the symbiotic effectiveness in some leguminous, cereal, and vegetable crops.

\section{Materials and Methods}

\subsection{Source of Biofertilizer}

A peat-based biofertilizer produced from B. japonicum SAY3-7 plus B. elkanii BLY3-8 and S. griseoflavus $\mathrm{P} 4$ was used. This biofertilizer was produced in a previous study [25] using the following processes. First, $100 \mathrm{~g}$ of sterilized peat soil imported from Myanmar was put in a polyethylene bag. Then, $20 \mathrm{~mL}$ of each of the Bradyrhizobium strains (B. japonicum SAY3-7 and B. elkanii BLY3-8) were added. Next, spores of $S$. griseoflavus P4 from IMA-2 plates were collected and put in the polyethylene bag. Finally, the polyethylene bag was put in a black polyethylene bag to protect the bacteria from 
light. The population densities of the Bradyrhizobium strains and S. griseoflavus P4 were $10^{8}$ cells $\mathrm{g}^{-1}$ at the time of use.

\subsection{Evaluation of Biofertilizer on Growth of Cereal and Leguminous Plants}

Three cereal crops, rice (Oryza sativa L.) cv. Manawthuka and wheat (Triticum aestivum L.) (Plant nutrition laboratory, Kyushu university, Japan), and maize (Zea mays L.) cv. Kakuteru (Nihon nousan shubyo Co., Ltd., Japan); three horticultural crops, komatsuna (Brassica rapa L.) and spinach (Spinacia oleracea L.) cv. O-rai hourennsou, Japanease radish (Raphanus sativus L.) cv. Tokinashi-daikon (Nihon nousan shubyo Co., Ltd., Japan); and six leguminous plants, common bean (Phaseolus vulgaris L.) cv. Suzinashi-saitou (Nihon nousan shubyo Co., Ltd.), sweet pea (Lathyrus odoratus L.) cv. spring endo (Nakahara seed product Co., Ltd.), mung bean (Vigna radiate L. Wilzeck) cv. Yezin-1, black gram (Vigna mungo L. Hepper) cv. Yezin-11, cowpea (Vigna unguiculata L. Walp) cv. Yezin-8 and soybean (Glycine max (L.) Merr.) cv. Yezin-6 (Department of agriculture, Yezin, Myanmar) were used to evaluate the effects the biofertilizer on plant growth under nitrogen-free and nitrogen-supplemented conditions. The seeds were surface-sterilized by soaking in $2.5 \%$ sodium hypochlorite for $5 \mathrm{~min}$, rinsed five times in $10 \mathrm{~mL}$ of $99.5 \%$ ethanol, and washed five times in sterilized half-strength modified Hoagland nutrient (MHN) solution [26] to remove any traces of the sodium hypochlorite and ethanol. Seven seeds per pot were grown in 1-L plastic pots filled with $1.2 \mathrm{~L}$ vermiculite and $0.6 \mathrm{~L}$ MHN solution containing $0.5 \mathrm{mM} \mathrm{NaNO}_{3}$ and autoclaved at $120^{\circ} \mathrm{C}$ for $20 \mathrm{~min}$. The vermiculite was sieved through a $4-\mathrm{mm}$ sieve. A liquid suspension of 10 -fold diluted biofertilizer was inoculated at $5 \mathrm{~mL}$ per seed. Five plants were maintained for 10 days after sowing. The plants were cultivated in a Phytotron $\left(25^{\circ} \mathrm{C}\right.$ and $75 \%$ relative humidity) for 30 days. When the pot weight decreased by about $400 \mathrm{~g}, 0.4 \mathrm{~L}$ of autoclaved MHN containing $0.5 \mathrm{mM} \mathrm{NaNO}_{3}$ was added for the first watering, and subsequently, deionized water was used continuously for watering up to the starting weight of each pot. A completely randomized design was used with three replications. Five replicate plants were used from pots of the various crops to measure the growth parameters. This experiment was conducted from March to April 2018.

\subsection{Evaluation of Biofertilizer on Nitrogen Fixation of Leguminous Plants}

Two mung bean varieties; mung bean (Vigna radiate L. Wilzeck) cv. greenmappe (Nakahara seed product Co., Ltd., Japn) and mung bean (Vigna radiata) cv. Yezin-1; two cowpea varities; cowpea (Vigna unguiculata) cv. rokushakusasage (Nakahara seed product Co., Ltd., Japan) and cowpea (Vigna unguiculata) cv. Yezin-8, soybean (Glycine max) cv. Akisirome (Plant nutrition laboratory, Kyushu university, Japan) and soybean (Glycine max) cv. Yezin-6 were used to evaluate the effects of the biofertilizer on plant growth, nodulation, and nitrogen fixation under the nitrogen-supplemented condition. The growth conditions under $\mathrm{N}$-supplementation were as described above. Three replicate plants of the various crops from each pot were used to measure the acetylene reduction activity (ARA) according to Haider et al. [27]. This experiment was conducted in May 2018.

\subsection{Evaluation of Biofertilizer on Growth, Nitrogen Fixation and Seed Yield of Three Legume}

Before cultivation, the Futsukaichi soil used was mixed thoroughly. Then, a soil sample was collected to analyze its physicochemical properties. The collected soil samples were spread and air-dried at room temperature for $24 \mathrm{~h}$. Then, they were crushed by hand and sieved using a 2-mm sieve. They were stored at $4{ }^{\circ} \mathrm{C}$ until soil analysis. The soil $\mathrm{pH}_{\mathrm{H} 2 \mathrm{O}}\left(1: 2.5\right.$ soil: $\left.\mathrm{H}_{2} \mathrm{O}\right)$ was measured using a pH meter (Beckman $\phi 360 \mathrm{pH} / \mathrm{Temp} / \mathrm{mV}$ Meter; Beckmann Coulter, Brea, CA, USA). The nutrients in the soil were digested using the salicylic acid- $\mathrm{H}_{2} \mathrm{SO}_{4}$-hydrogen peroxide $\left(\mathrm{H}_{2} \mathrm{O}_{2}\right)$ digestion method [28]; total $\mathrm{N}$ was determined using the indophenol method [29], and total phosphorus (P) using the ascorbic acid method [30]. Mineralizable $\mathrm{N}$ was assessed using the soil incubation method [31], and the mineralizable $\mathrm{N}$ content was measured as in Cataldo et al. [29]. Available P was measured using the Truog method [32]. The cation exchange capacity (CEC) and exchangeable cations were 
extracted using the ammonium acetate shaking method [33] and analyzed using an atomic absorption spectrophotometer (Z-5300, Hitachi, Tokyo, Japan).

For pot preparation, a 1/5000 Wagner pot was filled with $3.7 \mathrm{~kg}$ (oven-dry basis) of Futsukaichi soil. Then, compound fertilizer (Kumiai Mame-kasei 300, Ryoto Fertilizer Co., Ltd., Ooita, Japan) containing $3 \% \mathrm{~N}, 10 \% \mathrm{P}_{2} \mathrm{O}_{5}$, and $10 \% \mathrm{~K}_{2} \mathrm{O}$ was applied at a rate of $4 \mathrm{~g}$ pot- 1 at the time of pot preparion. The water-holding capacity was kept at $50 \%$ at the time of sowing. To prepare the inoculum, a liquid suspension of 10-fold diluted biofertilizer was used at a rate of $5 \mathrm{~mL}$ per seed. Five seeds were sown per pot. Fourteen days after sowing, the plants were thinned to two plants per pot. Pesticides were sprayed as necessary. Plant samples were collected from three growing stages: V3 (three unfolded trifoliate leaves), R2 (full bloom stage), and R3.5 (early pod-fill stage). At R8 (maturity stage), the mature plants were harvested to determine the yield.

To measure nitrogen fixation, the ARA was measured at R2 and R3.5. After the ARA assay, the number of nodules was counted, and then shoots, roots, and nodules were collected separately and dried at $70{ }^{\circ} \mathrm{C}$ for $72 \mathrm{~h}$ to record their dry weights.

At the V3, R2, and R3.5 stages, the dried shoots were ground into a powder using a mill. After digesting the nutrients using the $\mathrm{H}_{2} \mathrm{SO}_{4}-\mathrm{H}_{2} \mathrm{O}_{2}$ digestion method, the total $\mathrm{N}$ in the shoot was measured by the indophenol method; total $\mathrm{P}$ was analyzed using the ascorbic acid method, and total $\mathrm{K}$ was measured using atomic absorption spectrophotometry. Total N, P and K uptakes were calculated by multiplying nutrient content and shoot dry weight.

At the R8 stage, the plants were cut at the cotyledon nodes to determine the yield parameters, such as the number of pods per plant, number of seeds per pod, and 100-seed weight. This experiment was conducted from June to September 2018.

\subsection{Statistical Analysis}

The data were analyzed using the STATISTIX 8 software package (Analytical Software, Tallahassee, FL, USA), and the means were compared using Tukey's honestly significant difference (HSD) test, with a $p$-value $<0.05$ taken to indicate statistical significance.

\section{Results}

\subsection{Effects of Biofertilizer on Plant Growth of Cereal, Leguminous, and Vegetable Crops}

Table 1 summarizes the effects of biofertilizer application on plant growth. Under the N-limited condition, the shoot and root growth of mung bean, cowpea, and soybean were significantly promoted by the biofertilizer compared with the control, but not in the other tested cereals or the leguminous and vegetable crops. With $\mathrm{N}$ supplementation, the biofertilizer application significantly increased the shoot and root growth of mung bean, cowpea, and soybean compared with the control. Moreover, the plants to which biofertilizer was applied showed increased shoot growth in komatsuna, and root growth in wheat, maize, sweet pea, and common bean. These results demonstrate that the biofertilizer used in our study was effective in mung bean, cowpea, and soybean regardless of $\mathrm{N}$ application.

\subsection{Effects of Biofertilizer on Plant Growth, Nodulation and Nitrogen Fixation of Leguminous Crops}

Table 2 shows the effects of biofertilizer application on plant growth, nodulation, and nitrogen fixation in three leguminous crops. Compared with the control, the biofertilizer significantly promoted these in mung bean, cowpea, and soybean. No nodules formed in the control treatment; consequently, nitrogen fixation did not occur. However, the biofertilizer was compatible with nodule formation and nitrogen fixation in mung beans, cowpeas, and soybeans. 
Table 1. Effect of biofertilizer on RDW and SDW (g pot ${ }^{-1}$ ) of various crops with or without nitrogen application.

\begin{tabular}{cccccc}
\hline \multirow{2}{*}{ Crops } & Treatment & \multicolumn{2}{c}{ Without N Application } & \multicolumn{2}{c}{ With N Application } \\
\cline { 2 - 5 } & & RDW (g pot $^{-\mathbf{1}}$ ) & SDW (g pot $^{-\mathbf{1}}$ ) & RDW (g pot $^{\mathbf{- 1}}$ ) & SDW (g pot $^{-\mathbf{1}}$ ) \\
\hline \multirow{2}{*}{ Rice } & Control & $0.08 \pm 0.01 \mathrm{a}$ & $0.10 \pm 0.00 \mathrm{a}$ & $0.20 \pm 0.02 \mathrm{a}$ & $0.35 \pm 0.02 \mathrm{a}$ \\
& Biofertilizer & $0.10 \pm 0.00 \mathrm{a}$ & $0.11 \pm 0.00 \mathrm{a}$ & $0.22 \pm 0.04 \mathrm{a}$ & $0.37 \pm 0.03 \mathrm{a}$ \\
Wheat & Control & $0.30 \pm 0.02 \mathrm{a}$ & $0.17 \pm 0.01 \mathrm{a}$ & $0.51 \pm 0.04 \mathrm{~b}$ & $0.46 \pm 0.03 \mathrm{a}$ \\
& Biofertilizer & $0.32 \pm 0.03 \mathrm{a}$ & $0.19 \pm 0.01 \mathrm{a}$ & $0.61 \pm 0.01 \mathrm{a}$ & $0.49 \pm 0.03 \mathrm{a}$ \\
Maize & Control & $0.50 \pm 0.09 \mathrm{a}$ & $0.42 \pm 0.10 \mathrm{a}$ & $0.66 \pm 0.02 \mathrm{~b}$ & $0.94 \pm 0.03 \mathrm{a}$ \\
& Biofertilizer & $0.56 \pm 0.02 \mathrm{a}$ & $0.48 \pm 0.04 \mathrm{a}$ & $0.78 \pm 0.05 \mathrm{a}$ & $1.04 \pm 0.08 \mathrm{a}$ \\
Komatusna & Control & $0.01 \pm 0.00 \mathrm{a}$ & $0.14 \pm 0.01 \mathrm{a}$ & $0.08 \pm 0.00 \mathrm{a}$ & $0.30 \pm 0.04 \mathrm{~b}$ \\
& Biofertilizer & $0.01 \pm 0.00 \mathrm{a}$ & $0.16 \pm 0.01 \mathrm{a}$ & $0.09 \pm 0.02 \mathrm{a}$ & $0.42 \pm 0.04 \mathrm{a}$ \\
Spinach & Control & $0.03 \pm 0.00 \mathrm{a}$ & $0.08 \pm 0.01 \mathrm{a}$ & $0.04 \pm 0.01 \mathrm{a}$ & $0.23 \pm 0.02 \mathrm{a}$ \\
& Biofertilizer & $0.03 \pm 0.00 \mathrm{a}$ & $0.09 \pm 0.00 \mathrm{a}$ & $0.06 \pm 0.01 \mathrm{a}$ & $0.31 \pm 0.04 \mathrm{a}$ \\
Raddish & Control & $0.03 \pm 0.00 \mathrm{a}$ & $0.18 \pm 0.00 \mathrm{a}$ & $0.09 \pm 0.02 \mathrm{a}$ & $0.66 \pm 0.04 \mathrm{a}$ \\
& Biofertilizer & $0.03 \pm 0.01 \mathrm{a}$ & $0.20 \pm 0.02 \mathrm{a}$ & $0.09 \pm 0.02 \mathrm{a}$ & $0.72 \pm 0.03 \mathrm{a}$ \\
Sweet pea & Control & $0.44 \pm 0.02 \mathrm{a}$ & $1.40 \pm 0.03 \mathrm{a}$ & $0.53 \pm 0.07 \mathrm{~b}$ & $1.58 \pm 0.15 \mathrm{a}$ \\
& Biofertilizer & $0.46 \pm 0.03 \mathrm{a}$ & $1.42 \pm 0.04 \mathrm{a}$ & $0.73 \pm 0.07 \mathrm{a}$ & $1.65 \pm 0.12 \mathrm{a}$ \\
Common bean & Control & $0.53 \pm 0.10 \mathrm{a}$ & $1.63 \pm 0.20 \mathrm{a}$ & $0.96 \pm 0.09 \mathrm{~b}$ & $2.13 \pm 0.17 \mathrm{a}$ \\
& Biofertilizer & $0.67 \pm 0.02 \mathrm{a}$ & $1.75 \pm 0.18 \mathrm{a}$ & $1.22 \pm 0.06 \mathrm{a}$ & $2.35 \pm 0.17 \mathrm{a}$ \\
Mung bean & Control & $0.35 \pm 0.00 \mathrm{~b}$ & $0.69 \pm 0.03 \mathrm{~b}$ & $0.52 \pm 0.03 \mathrm{~b}$ & $0.95 \pm 0.02 \mathrm{~b}$ \\
& Biofertilizer & $0.41 \pm 0.01 \mathrm{a}$ & $0.95 \pm 0.06 \mathrm{a}$ & $0.63 \pm 0.02 \mathrm{a}$ & $1.11 \pm 0.04 \mathrm{a}$ \\
Black gram & Control & $0.29 \pm 0.02 \mathrm{~b}$ & $0.32 \pm 0.02 \mathrm{a}$ & $0.39 \pm 0.02 \mathrm{a}$ & $0.44 \pm 0.04 \mathrm{a}$ \\
& Biofertilizer & $0.32 \pm 0.01 \mathrm{a}$ & $0.35 \pm 0.02 \mathrm{a}$ & $0.40 \pm 0.03 \mathrm{a}$ & $0.47 \pm 0.02 \mathrm{a}$ \\
Cowpea & Control & $0.60 \pm 0.04 \mathrm{~b}$ & $1.25 \pm 0.08 \mathrm{~b}$ & $1.06 \pm 0.04 \mathrm{~b}$ & $1.68 \pm 0.07 \mathrm{~b}$ \\
& Biofertilizer & $0.78 \pm 0.08 \mathrm{a}$ & $1.52 \pm 0.01 \mathrm{a}$ & $1.29 \pm 0.07 \mathrm{a}$ & $2.37 \pm 0.13 \mathrm{a}$ \\
Soybean & Control & $0.65 \pm 0.04 \mathrm{~b}$ & $1.80 \pm 0.07 \mathrm{~b}$ & $1.21 \pm 0.04 \mathrm{~b}$ & $2.23 \pm 0.10 \mathrm{~b}$ \\
& Biofertilizer & $0.95 \pm 0.14 \mathrm{a}$ & $2.25 \pm 0.12 \mathrm{a}$ & $1.57 \pm 0.06 \mathrm{a}$ & $2.92 \pm 0.10 \mathrm{a}$ \\
\hline
\end{tabular}

For each cultivar, mean values with the same letters in each column are not significantly different at $p<0.05$ (Tukey's test). RDW: Root dry weight, SDW: shoot dry weight.

Table 2. Effects of biofertilizer on NN, NDW, RDW, SDW, and ARA of mung beans, cowpeas and soybeans at 30 DAS.

\begin{tabular}{|c|c|c|c|c|c|c|}
\hline Crop & Treatment & $\begin{array}{c}\text { NN } \\
\text { (no. pot } \\
\text { (n) }\end{array}$ & $\begin{array}{c}\text { NDW } \\
\left(g_{\text {pot }^{-1}}\right)\end{array}$ & $\begin{array}{c}\text { RDW } \\
\left(\operatorname{g~pot}^{-1}\right)\end{array}$ & $\begin{array}{c}\text { SDW } \\
\left(\mathrm{g} \mathrm{pot}^{-1}\right)\end{array}$ & $\begin{array}{c}\text { ARA } \\
\left(\mu \mathrm{mol} \mathrm{C} \mathrm{H}_{4} \mathrm{~h}^{-1} \text { plant }^{-1}\right)\end{array}$ \\
\hline \multirow[t]{2}{*}{ Mung bean (JP) } & Control & $0.0 \pm 0.0 \mathrm{~b}$ & $0.00 \pm 0.00 \mathrm{~b}$ & $0.50 \pm 0.04 b$ & $0.91 \pm 0.01 \mathrm{~b}$ & $0.00 \pm 0.00 \mathrm{~b}$ \\
\hline & Biofertilizer & $17.3 \pm 2.1 \mathrm{a}$ & $0.02 \pm 0.00 \mathrm{a}$ & $0.61 \pm 0.03 \mathrm{a}$ & $1.06 \pm 0.08 \mathrm{a}$ & $0.43 \pm 0.04 \mathrm{a}$ \\
\hline \multirow[t]{2}{*}{ Mung bean (MM) } & Control & $0.0 \pm 0.0 \mathrm{~b}$ & $0.00 \pm 0.00 \mathrm{~b}$ & $0.64 \pm 0.03 b$ & $1.06 \pm 0.06 \mathrm{~b}$ & $0.00 \pm 0.00 \mathrm{~b}$ \\
\hline & Biofertilizer & $16.7 \pm 0.5 \mathrm{a}$ & $0.02 \pm 0.00 \mathrm{a}$ & $0.75 \pm 0.05 \mathrm{a}$ & $1.27 \pm 0.07 \mathrm{a}$ & $0.51 \pm 0.13 \mathrm{a}$ \\
\hline \multirow[t]{2}{*}{ Cowpea (JP) } & Control & $0.0 \pm 0.0 \mathrm{~b}$ & $0.00 \pm 0.00 \mathrm{~b}$ & $0.94 \pm 0.03 \mathrm{~b}$ & $1.45 \pm 0.05 b$ & $0.00 \pm 0.00 \mathrm{~b}$ \\
\hline & Biofertilizer & $23.0 \pm 1.4 \mathrm{a}$ & $0.02 \pm 0.00 \mathrm{a}$ & $1.08 \pm 0.02 \mathrm{a}$ & $1.73 \pm 0.08 \mathrm{a}$ & $0.53 \pm 0.07 \mathrm{a}$ \\
\hline \multirow[t]{2}{*}{ Cowpea (MM) } & Control & $0.0 \pm 0.0 \mathrm{~b}$ & $0.00 \pm 0.00 \mathrm{~b}$ & $1.11 \pm 0.03 \mathrm{~b}$ & $2.15 \pm 0.04 b$ & $0.00 \pm 0.00 \mathrm{~b}$ \\
\hline & Biofertilizer & $21.0 \pm 2.2 \mathrm{a}$ & $0.02 \pm 0.00 \mathrm{a}$ & $1.28 \pm 0.06 \mathrm{a}$ & $2.40 \pm 0.09 \mathrm{a}$ & $0.49 \pm 0.07 \mathrm{a}$ \\
\hline \multirow[t]{2}{*}{ Soybean (JP) } & Control & $0.0 \pm 0.0 \mathrm{~b}$ & $0.00 \pm 0.00 \mathrm{~b}$ & $1.10 \pm 0.02 b$ & $1.97 \pm 0.03 b$ & $0.00 \pm 0.00 b$ \\
\hline & Biofertilizer & $12.3 \pm 1.7 \mathrm{a}$ & $0.04 \pm 0.00 \mathrm{a}$ & $1.21 \pm 0.04 \mathrm{a}$ & $2.23 \pm 0.10 \mathrm{a}$ & $1.01 \pm 0.04 \mathrm{a}$ \\
\hline \multirow[t]{2}{*}{ Soybean (MM) } & Control & $0.0 \pm 0.0 \mathrm{~b}$ & $0.00 \pm 0.00 \mathrm{~b}$ & $1.32 \pm 0.09 \mathrm{~b}$ & $2.69 \pm 0.07 b$ & $0.00 \pm 0.00 \mathrm{~b}$ \\
\hline & Biofertilizer & $15.0 \pm 0.8 \mathrm{a}$ & $0.04 \pm 0.00 \mathrm{a}$ & $1.57 \pm 0.06 \mathrm{a}$ & $2.92 \pm 0.10 \mathrm{a}$ & $1.05 \pm 0.07 \mathrm{a}$ \\
\hline
\end{tabular}

For each cultivar, mean values with the same letters in each column are not significantly different at $p<0.05$ (Tukey's test). JP: Japanese variety, MM: Myanmar variety, NN: nodule number, NDW: nodule dry weight, RDW: root dry weight, SDW: shoot dry weight, ARA: acetylene reduction activity, DAS: days after sowing.

3.3. Effects of Biofertilizer on Symbiotic Nitrogen Fixation and Nutrient Uptake of Mung Bean, Cowpea, and Soybean Cultivated in Futsukaichi Soil

Table 3 describes the physicochemical properties of the Futsukaichi soil. The soil $\mathrm{pH}$ was 6.61 (soil:water, 1:2.5). The soil contained $80 \mathrm{mg}$ of total nitrogen, $0.39 \mathrm{mg}$ of available nitrogen, $120 \mathrm{mg}$ total phosphorus $(\mathrm{P})$, and $33.89 \mathrm{mg}$ available nitrogen $(\mathrm{N})$ per $100 \mathrm{~g}$ soil. The cation exchange capacity (CEC) of the soil was $9.96 \mathrm{cmolc} \mathrm{kg}^{-1}$. There were $0.56,3.12$, and $0.26 \mathrm{c}$ molc kg${ }^{-1}$ of exchangeable potassium $(\mathrm{K})$, calcium $(\mathrm{Ca})$, and magnesium $(\mathrm{Mg})$, respectively. 
Table 3. Physicochemical properties of Futsukaichi soil.

\begin{tabular}{|c|c|}
\hline Physicochemical Property & Values \\
\hline Soil pH (Soil: $\left.\mathrm{H}_{2} \mathrm{O} ; 1: 2.5\right)$ & 6.61 \\
\hline Total N (mg N/100 g soil) & $80 \mathrm{mg}$ \\
\hline Total $\mathrm{P}_{2} \mathrm{O}_{5}\left(\mathrm{mg} \mathrm{P}_{2} \mathrm{O}_{5} / 100 \mathrm{~g}\right.$ soil $)$ & $120 \mathrm{mg}$ \\
\hline Available N (mg N/100 g soil) & $0.34 \mathrm{mg}$ \\
\hline Available $\mathrm{P}\left(\mathrm{mg} \mathrm{P}_{2} \mathrm{O}_{5} / 100 \mathrm{~g}\right.$ soil $)$ & $33.89 \mathrm{mg}$ \\
\hline $\mathrm{CEC}\left(\mathrm{c} \mathrm{mol}_{\mathrm{C}} \mathrm{Kg}^{-1}\right)$ & $9.94 \mathrm{c} \mathrm{mol}_{\mathrm{C}} \mathrm{Kg}^{-1}$ \\
\hline Exc. $\mathrm{K}\left(\mathrm{c} \mathrm{mol}_{\mathrm{c}} \mathrm{Kg}^{-1}\right)$ & $0.56 \mathrm{c} \mathrm{mol}_{\mathrm{C}} \mathrm{Kg}^{-1}$ \\
\hline Exc. Ca $\left(\mathrm{c} \mathrm{mol}_{\mathrm{c}} \mathrm{Kg}^{-1}\right)$ & $3.12 \mathrm{c} \mathrm{mol}_{\mathrm{C}} \mathrm{Kg}^{-1}$ \\
\hline Exc. $\mathrm{Mg}\left(\mathrm{c} \mathrm{mol}_{\mathrm{C}} \mathrm{Kg}^{-1}\right)$ & $0.26 \mathrm{c} \mathrm{mol}_{\mathrm{C}} \mathrm{Kg}^{-1}$ \\
\hline
\end{tabular}

CEC: Cation exchange capacity, Exc: Exchangeable

Table 4 presents the effects of the biofertilizer on the growth of mung beans, cowpeas, and soybeans. The application of biofertilizer significantly increased the shoot biomass of mung beans and soybeans at all sampling stages compared with the control. However, the growth-promoting effect in cowpeas occurred at the early growth stages (V3 and R2), but not at the later growth stages (R3.5 and R8 (maturity stage)).

Table 4. Effect of biofertilizer on SDW ( $\mathrm{g} \mathrm{pot}^{-1}$ ) of mung beans, cowpeas and soybeans at different growth stages.

\begin{tabular}{cccccc}
\hline Crop & Treatment & V3 & R2 & R3.5 & R8 \\
\hline Mung bean (JP) & Control & $0.31 \pm 0.02 \mathrm{~b}$ & $16.27 \pm 0.62 \mathrm{~b}$ & $24.88 \pm 0.41 \mathrm{~b}$ & $21.89 \pm 1.33 \mathrm{~b}$ \\
& Biofertilizer & $0.36 \pm 0.01 \mathrm{a}$ & $17.97 \pm 0.07 \mathrm{a}$ & $27.49 \pm 1.09 \mathrm{a}$ & $26.26 \pm 1.16 \mathrm{a}$ \\
Mung bean (MM) & Control & $0.29 \pm 0.02 \mathrm{~b}$ & $14.38 \pm 0.58 \mathrm{~b}$ & $27.76 \pm 1.42 \mathrm{~b}$ & $39.74 \pm 0.35 \mathrm{~b}$ \\
& Biofertilizer & $0.35 \pm 0.01 \mathrm{a}$ & $17.32 \pm 1.07 \mathrm{a}$ & $32.05 \pm 0.53 \mathrm{a}$ & $42.23 \pm 0.76 \mathrm{a}$ \\
Cowpea (JP) & Control & $0.38 \pm 0.04 \mathrm{~b}$ & $15.67 \pm 0.92 \mathrm{~b}$ & $25.89 \pm 1.77 \mathrm{a}$ & $19.51 \pm 5.06 \mathrm{a}$ \\
& Biofertilizer & $0.47 \pm 0.01 \mathrm{a}$ & $18.49 \pm 0.66 \mathrm{a}$ & $27.39 \pm 0.83 \mathrm{a}$ & $21.93 \pm 2.64 \mathrm{a}$ \\
Cowpea (MM) & Control & $0.45 \pm 0.03 \mathrm{~b}$ & $15.23 \pm 0.82 \mathrm{~b}$ & $29.11 \pm 0.59 \mathrm{a}$ & $26.66 \pm 3.11 \mathrm{a}$ \\
& Biofertilizer & $0.56 \pm 0.03 \mathrm{a}$ & $17.64 \pm 0.38 \mathrm{a}$ & $30.62 \pm 0.49 \mathrm{a}$ & $28.38 \pm 1.59 \mathrm{a}$ \\
Soybean (JP) & Control & $0.35 \pm 0.03 \mathrm{~b}$ & $16.72 \pm 0.32 \mathrm{~b}$ & $32.00 \pm 1.04 \mathrm{~b}$ & $32.13 \pm 1.29 \mathrm{~b}$ \\
& Biofertilizer & $0.45 \pm 0.02 \mathrm{a}$ & $17.77 \pm 0.22 \mathrm{a}$ & $35.64 \pm 1.00 \mathrm{a}$ & $35.50 \pm 0.45 \mathrm{a}$ \\
Soybean (MM) & Control & $0.35 \pm 0.03 \mathrm{~b}$ & $16.55 \pm 0.63 \mathrm{~b}$ & $28.96 \pm 1.44 \mathrm{~b}$ & $39.45 \pm 1.52 \mathrm{~b}$ \\
& Biofertilizer & $0.48 \pm 0.02 \mathrm{a}$ & $19.03 \pm 0.83 \mathrm{a}$ & $33.20 \pm 1.07 \mathrm{a}$ & $43.58 \pm 2.03 \mathrm{a}$ \\
\hline
\end{tabular}

For each cultivar, mean values with the same letters in each column are not significantly different at $p<0.05$ (Tukey's test). JP: Japanese variety, MM: Myanmar variety, SDW: shoot dry weight, V3: three unfolded trifoliate leaves, R2: full bloom stage, R3.5: early pod-fill stage, R8: maturity stage.

Tables 5 and 6 describe the effects of the biofertilizer on symbiotic nitrogen fixation in the mung bean, cowpea, and soybean. The biofertilizer significantly improved nodule formation and nitrogen fixation by mung beans and soybeans at R2 and R3.5 compared with the control, but not the nodulation and nitrogen-fixation ability of cowpea.

Table 7 shows the effects of the biofertilizer on $\mathrm{N}$ uptake of mung bean, cowpea, and soybean. The biofertilizer significantly increased the $\mathrm{N}$ uptake of mung bean and soybean at V3, R2, and R3.5 compared with the control. By contrast, a significant increase in the $\mathrm{N}$ uptake of cowpea occurred at V3 stage, but not at R2 and R3.5. Table 8 shows the effects of the biofertilizer on P uptake by mung bean, cowpea, and soybean. The biofertilizer application significantly increased the P uptake of the Myanmar mung bean variety at all stages compared with the control. In comparison, in the Japanese mung bean variety, the significant increase in P uptake occurred at V3. In cowpea, a significant increase in P uptake occurred at V3, but not at R2 and R3.5. The biofertilizer significantly increased the P uptake of soybean at all stages compared with the control. Table 9 shows the effects of the biofertilizer on the $\mathrm{K}$ uptake of mung bean, cowpea, and soybean. The biofertilizer significantly increased the K uptake of the Myanmar mung bean variety at the V3, R2, and R3.5 stages compared with the control, whereas the significant increase in K uptake occurred at V3 in the Japanese mung bean variety. Similarly, the application of biofertilizer significantly increased the K content of the Myanmar cowpea variety at 
V3, R2, and R3.5 compared with the control, whereas the significant increase in K uptake occurred at V3 and R2 in the Japanese cowpea variety. In soybean, the use of the biofertilizer significantly increased the $\mathrm{K}$ uptake at V3 in Japan soybean variety and at V3 and R2 in Myanmar soybean variety compared with the control, but not at the R8 growth stage [in both Japan and Myanmar soybean].

Table 5. Effect of biofertilizer on NN, NDW and ARA of mung beans, cowpeas and Soybeans at R2 (full bloom stage).

\begin{tabular}{|c|c|c|c|c|}
\hline Crop & Treatment & $\begin{array}{c}\text { NN } \\
\left(\text { no. } \text { pot }^{-1}\right)\end{array}$ & $\begin{array}{c}\text { NDW } \\
\left(\mathrm{g} \mathrm{pot}^{-1}\right)\end{array}$ & $\begin{array}{c}\text { ARA } \\
\left(\mu \mathrm{mol} \mathrm{C} \mathrm{H}_{4} \mathrm{~h}^{-1} \operatorname{pot}^{-1}\right)\end{array}$ \\
\hline \multirow[t]{2}{*}{ Mung bean (JP) } & Control & $7.3 \pm 1.2 b$ & $0.06 \pm 0.01 \mathrm{~b}$ & $0.76 \pm 0.06 \mathrm{~b}$ \\
\hline & Biofertilizer & $13.0 \pm 1.6 \mathrm{a}$ & $0.10 \pm 0.01 \mathrm{a}$ & $1.32 \pm 0.17 \mathrm{a}$ \\
\hline \multirow[t]{2}{*}{ Mung bean (MM) } & Control & $22.7 \pm 1.9 \mathrm{~b}$ & $0.14 \pm 0.03 b$ & $2.66 \pm 0.28 b$ \\
\hline & Biofertilizer & $29.3 \pm 3.3 \mathrm{a}$ & $0.27 \pm 0.04 \mathrm{a}$ & $4.23 \pm 0.41 \mathrm{a}$ \\
\hline \multirow{2}{*}{ Cowpea (JP) } & Control & $17.7 \pm 2.1 \mathrm{a}$ & $0.20 \pm 0.00 \mathrm{a}$ & $3.03 \pm 0.64 \mathrm{a}$ \\
\hline & Biofertilizer & $2.0 \pm 5.0 \mathrm{a}$ & $0.22 \pm 0.01 \mathrm{a}$ & $3.58 \pm 0.71 \mathrm{a}$ \\
\hline \multirow[t]{2}{*}{ Cowpea (MM) } & Control & $25.7 \pm 4.2 \mathrm{a}$ & $0.23 \pm 0.02 \mathrm{a}$ & $7.53 \pm 2.31 \mathrm{a}$ \\
\hline & Biofertilizer & $39.0 \pm 7.0 \mathrm{a}$ & $0.25 \pm 0.03 \mathrm{a}$ & $9.37 \pm 2.14 \mathrm{a}$ \\
\hline \multirow[t]{2}{*}{ Soybean (JP) } & Control & $58.33 \pm 6.2 b$ & $0.32 \pm 0.25 b$ & $10.11 \pm 0.09 b$ \\
\hline & Biofertilizer & $113.33 \pm 26.2 \mathrm{a}$ & $0.54 \pm 0.14 \mathrm{a}$ & $11.68 \pm 0.41 \mathrm{a}$ \\
\hline \multirow{2}{*}{ Soybean (MM) } & Control & $36.33 \pm 3.9 b$ & $0.19 \pm 0.07 b$ & $7.73 \pm 0.93 b$ \\
\hline & Biofertilizer & $66.00 \pm 18.5 \mathrm{a}$ & $0.37 \pm 0.09 \mathrm{a}$ & $10.76 \pm 1.04 \mathrm{a}$ \\
\hline
\end{tabular}

For each cultivar, mean values with the same letters in each column are not significantly different at $p<0.05$ (Tukey's test). JP: Japanese variety, MM: Myanmar variety, NN: nodule number, NDW: nodule dry weight, ARA: acetylene reduction activity.

Table 6. Effect of biofertilizer on NN, NDW and ARA of mung beans, cowpeas and soybeans at R3.5 (early pod-fill stage).

\begin{tabular}{|c|c|c|c|c|}
\hline Crop & Treatment & $\begin{array}{c}\text { NN } \\
\left(\text { No. } \text { pot }^{-1}\right)\end{array}$ & $\begin{array}{c}\text { NDW } \\
\left(\mathrm{g} \mathrm{pot}^{-1}\right)\end{array}$ & $\begin{array}{c}\text { ARA } \\
\left(\mu \mathrm{mol} \mathrm{C} \mathrm{H}_{4} \mathrm{~h}^{-1} \text { pot }^{-1}\right)\end{array}$ \\
\hline \multirow[t]{2}{*}{ Mung bean (JP) } & Control & $60.0 \pm 4.9 \mathrm{~b}$ & $0.54 \pm 0.04 \mathrm{~b}$ & $47.01 \pm 2.69 \mathrm{~b}$ \\
\hline & Biofertilizer & $82.3 \pm 2.1 \mathrm{a}$ & $0.76 \pm 0.04 \mathrm{a}$ & $52.53 \pm 1.07 \mathrm{a}$ \\
\hline \multirow[t]{2}{*}{ Mung bean (MM) } & Control & $87.7 \pm 8.8 b$ & $0.93 \pm 0.05 b$ & $18.59 \pm 3.07 b$ \\
\hline & Biofertilizer & $111.0 \pm 3.7 \mathrm{a}$ & $1.21 \pm 0.06 \mathrm{a}$ & $31.01 \pm 3.02 \mathrm{a}$ \\
\hline \multirow[t]{2}{*}{ Cowpea (JP) } & Control & $158.3 \pm 8.6 \mathrm{a}$ & $1.11 \pm 0.16 \mathrm{a}$ & $26.19 \pm 4.32 \mathrm{a}$ \\
\hline & Biofertilizer & $172.0 \pm 12.0 \mathrm{a}$ & $1.32 \pm 0.11 \mathrm{a}$ & $32.23 \pm 2.05 a$ \\
\hline \multirow[t]{2}{*}{ Cowpea (MM) } & Control & $157.0 \pm 12.0 \mathrm{a}$ & $0.87 \pm 0.03 \mathrm{a}$ & $46.02 \pm 2.68 \mathrm{a}$ \\
\hline & Biofertilizer & $162.3 \pm 8.2 \mathrm{a}$ & $0.97 \pm 0.11 \mathrm{a}$ & $50.91 \pm 5.44 a$ \\
\hline \multirow[t]{2}{*}{ Soybean (JP) } & Control & $140.7 \pm 7.4 \mathrm{~b}$ & $1.47 \pm 0.05 \mathrm{~b}$ & $63.16 \pm 5.57 b$ \\
\hline & Biofertilizer & $181.3 \pm 21.7 \mathrm{a}$ & $1.62 \pm 0.06 \mathrm{a}$ & $75.42 \pm 3.67 \mathrm{a}$ \\
\hline \multirow{2}{*}{ Soybean (MM) } & Control & $113.0 \pm 8.8 \mathrm{~b}$ & $1.10 \pm 0.13 b$ & $46.62 \pm 3.46 b$ \\
\hline & Biofertilizer & $146.7 \pm 7.8 \mathrm{a}$ & $1.51 \pm 0.09 \mathrm{a}$ & $84.85 \pm 10.04 \mathrm{a}$ \\
\hline
\end{tabular}

For each cultivar, mean values with the same letters in each column are not significantly different at $p<0.05$ (Tukey's test). JP: Japanese variety, MM: Myanmar variety, NN: nodule number, NDW: nodule dry weight, ARA: acetylene reduction activity.

Table 7. Effect of biofertilizer on $\mathrm{N}$ uptake $\left(\mathrm{mg} \mathrm{pot}^{-1}\right)$ of mung beans, cowpeas and soybeans at different growth stage.

\begin{tabular}{ccccc}
\hline Crop & Treatment & V3 & R2 & R3.5 \\
\hline Mung bean (JP) & Control & $16.02 \pm 0.84 \mathrm{~b}$ & $203.92 \pm 22.96 \mathrm{~b}$ & $452.17 \pm 46.87 \mathrm{~b}$ \\
& Biofertilizer & $19.22 \pm 0.76 \mathrm{a}$ & $271.66 \pm 9.75 \mathrm{a}$ & $551.48 \pm 23.54 \mathrm{a}$ \\
Mung bean (MM) & Control & $15.02 \pm 1.31 \mathrm{~b}$ & $242.85 \pm 41.76 \mathrm{~b}$ & $547.06 \pm 60.47 \mathrm{~b}$ \\
& Biofertilizer & $18.40 \pm 0.65 \mathrm{a}$ & $321.88 \pm 21.22 \mathrm{a}$ & $683.20 \pm 63.57 \mathrm{a}$ \\
Cowpea (JP) & Control & $18.35 \pm 2.01 \mathrm{~b}$ & $315.69 \pm 19.63 \mathrm{a}$ & $687.56 \pm 51.53 \mathrm{a}$ \\
& Biofertilizer & $23.38 \pm 1.04 \mathrm{a}$ & $354.51 \pm 11.68 \mathrm{a}$ & $666.05 \pm 37.64 \mathrm{a}$ \\
Cowpea (MM) & Control & $23.25 \pm 1.51 \mathrm{~b}$ & $449.94 \pm 10.94 \mathrm{a}$ & $790.34 \pm 96.43 \mathrm{a}$ \\
& Biofertilizer & $28.16 \pm 2.25 \mathrm{a}$ & $477.13 \pm 34.69 \mathrm{a}$ & $877.11 \pm 40.68 \mathrm{a}$ \\
Soybean (JP) & Control & $21.14 \pm 1.78 \mathrm{~b}$ & $281.08 \pm 28.72 \mathrm{~b}$ & $664.16 \pm 24.46 \mathrm{~b}$ \\
& Biofertilizer & $28.24 \pm 1.34 \mathrm{a}$ & $346.09 \pm 50.50 \mathrm{a}$ & $777.03 \pm 41.12 \mathrm{a}$ \\
Soybean (MM) & Control & $20.80 \pm 1.88 \mathrm{~b}$ & $406.71 \pm 12.20 \mathrm{~b}$ & $740.31 \pm 45.07 \mathrm{~b}$ \\
& Biofertilizer & $29.26 \pm 1.87 \mathrm{a}$ & $466.06 \pm 9.35 \mathrm{a}$ & $866.08 \pm 54.32 \mathrm{a}$ \\
\hline
\end{tabular}

For each cultivar, mean values with the same letters in each column are not significantly different at $p<0.05$ (Tukey's test). JP: Japanese variety, MM: Myanmar variety, V3: three unfolded trifoliate leaves, R2: full bloom stage, R3.5: early pod-fill stage. 
Table 8. Effect of biofertilizer on $\mathrm{P}$ uptake $\left(\mathrm{mg} \mathrm{pot}^{-1}\right)$ of mung beans, cowpeas and soybeans at different growth stage.

\begin{tabular}{ccccc}
\hline Crop & Treatment & V3 & R2 & R3.5 \\
\hline Mung bean (JP) & Control & $1.58 \pm 0.07 \mathrm{~b}$ & $53.34 \pm 4.29 \mathrm{a}$ & $83.20 \pm 4.60 \mathrm{a}$ \\
& Biofertilizer & $2.05 \pm 0.07 \mathrm{a}$ & $51.24 \pm 3.98 \mathrm{a}$ & $81.75 \pm 4.32 \mathrm{a}$ \\
Mung bean (MM) & Control & $1.31 \pm 0.10 \mathrm{~b}$ & $37.51 \pm 4.05 \mathrm{~b}$ & $83.49 \pm 1.60 \mathrm{~b}$ \\
& Biofertilizer & $1.71 \pm 0.07 \mathrm{a}$ & $48.31 \pm 2.87 \mathrm{a}$ & $96.03 \pm 8.34 \mathrm{a}$ \\
Cowpea (JP) & Control & $1.73 \pm 0.16 \mathrm{~b}$ & $42.41 \pm 3.67 \mathrm{a}$ & $91.45 \pm 8.75 \mathrm{a}$ \\
& Biofertilizer & $2.23 \pm 0.13 \mathrm{a}$ & $50.55 \pm 3.51 \mathrm{a}$ & $88.34 \pm 8.57 \mathrm{a}$ \\
Cowpea (MM) & Control & $2.13 \pm 0.15 \mathrm{a}$ & $51.50 \pm 2.03 \mathrm{a}$ & $103.57 \pm 3.58 \mathrm{a}$ \\
& Biofertilizer & $2.35 \pm 0.01 \mathrm{a}$ & $57.93 \pm 2.76 \mathrm{a}$ & $107.03 \pm 2.77 \mathrm{a}$ \\
Soybean (JP) & Control & $2.15 \pm 0.21 \mathrm{~b}$ & $48.47 \pm 3.28 \mathrm{~b}$ & $84.82 \pm 3.76 \mathrm{~b}$ \\
& Biofertilizer & $2.89 \pm 0.14 \mathrm{a}$ & $57.64 \pm 1.98 \mathrm{a}$ & $107.31 \pm 8.25 \mathrm{a}$ \\
Soybean (MM) & Control & $2.08 \pm 0.17 \mathrm{~b}$ & $49.94 \pm 0.97 \mathrm{~b}$ & $87.13 \pm 3.06 \mathrm{~b}$ \\
& Biofertilizer & $2.89 \pm 0.18 \mathrm{a}$ & $60.10 \pm 4.43 \mathrm{a}$ & $101.09 \pm 5.09 \mathrm{a}$ \\
\hline
\end{tabular}

For each cultivar, mean values with the same letters in each column are not significantly different at $p<0.05$ (Tukey's test). JP: Japanese variety, MM: Myanmar variety, V3: three unfolded trifoliate leaves, R2: full bloom stage, R3.5: early pod-fill stage.

Table 9. Effect of biofertilizer on $\mathrm{K}$ uptake $\left(\mathrm{mg} \mathrm{pot}^{-1}\right)$ of mung beans, cowpeas and soybeans at different growth stage.

\begin{tabular}{ccccc}
\hline Crop & Treatment & V3 & R2 & R3.5 \\
\hline Mung bean (JP) & Control & $0.26 \pm 0.01 \mathrm{~b}$ & $7.58 \pm 0.68 \mathrm{a}$ & $9.07 \pm 0.91 \mathrm{a}$ \\
& Biofertilizer & $0.32 \pm 0.01 \mathrm{a}$ & $6.91 \pm 0.56 \mathrm{a}$ & $9.81 \pm 0.51 \mathrm{a}$ \\
Mung bean (MM) & Control & $0.25 \pm 0.02 \mathrm{~b}$ & $6.07 \pm 0.62 \mathrm{~b}$ & $10.19 \pm 0.69 \mathrm{~b}$ \\
& Biofertilizer & $0.33 \pm 0.01 \mathrm{a}$ & $8.10 \pm 0.22 \mathrm{a}$ & $12.87 \pm 0.52 \mathrm{a}$ \\
Cowpea (JP) & Control & $0.30 \pm 0.03 \mathrm{a}$ & $5.05 \pm 0.32 \mathrm{~b}$ & $9.55 \pm 0.56 \mathrm{a}$ \\
& Biofertilizer & $0.34 \pm 0.00 \mathrm{a}$ & $6.15 \pm 0.31 \mathrm{a}$ & $9.26 \pm 0.67 \mathrm{a}$ \\
Cowpea (MM) & Control & $0.33 \pm 0.02 \mathrm{~b}$ & $8.38 \pm 0.21 \mathrm{~b}$ & $11.96 \pm 0.54 \mathrm{~b}$ \\
& Biofertilizer & $0.47 \pm 0.03 \mathrm{a}$ & $9.62 \pm 1.10 \mathrm{a}$ & $14.33 \pm 0.66 \mathrm{a}$ \\
Soybean (JP) & Control & $0.24 \pm 0.02 \mathrm{~b}$ & $5.84 \pm 0.14 \mathrm{a}$ & $10.15 \pm 0.91 \mathrm{a}$ \\
& Biofertilizer & $0.32 \pm 0.01 \mathrm{a}$ & $6.33 \pm 0.45 \mathrm{a}$ & $12.07 \pm 0.92 \mathrm{a}$ \\
Soybean (MM) & Control & $0.24 \pm 0.02 \mathrm{~b}$ & $6.72 \pm 0.33 \mathrm{~b}$ & $10.86 \pm 0.95 \mathrm{a}$ \\
& Biofertilizer & $0.32 \pm 0.02 \mathrm{a}$ & $8.24 \pm 0.24 \mathrm{a}$ & $12.28 \pm 0.91 \mathrm{a}$ \\
\hline
\end{tabular}

For each cultivar, mean values with the same letters in each column are not significantly different at $p<0.05$ (Tukey's test). JP: Japanese variety, MM: Myanmar variety, V3: three unfolded trifoliate leaves, R2: full bloom stage, R3.5: early pod-fill stage.

Table 10 shows the effects of the biofertilizer on the yield and yield components of mung bean, cowpea, and soybean. The biofertilizer significantly increased the number of pods per pot in mung bean and soybean compared with the control, but not the seeds per pod or 100-seed weight. Moreover, the seed yield of mung bean and soybean increased with the biofertilizer application. In cowpea, the application of biofertilizer did not significantly increase the yield and yield components.

Table 10. Effect of biofertilizer on yield and yield components of mung beans, cowpeas and soybeans at R8 (maturity stage).

\begin{tabular}{cccccc}
\hline Crop & Treatment & $\begin{array}{c}\text { Pod. No } \\
\left(\text { no. } \text { pot }^{-1} \text { ) }\right.\end{array}$ & $\begin{array}{c}\text { Seeds Per Pod } \\
\left(\text { (no. pod }^{-1} \text { ) }\right.\end{array}$ & $\begin{array}{c}\text { 100 Seed } \\
\text { Weight (g) }\end{array}$ & $\begin{array}{c}\text { Seed Yield } \\
\text { (g pot }^{-\mathbf{1}} \text { ) }\end{array}$ \\
\hline Mung bean (JP) & Control & $22.0 \pm 2.2 \mathrm{~b}$ & $4.9 \pm 0.1 \mathrm{a}$ & $4.90 \pm 0.14 \mathrm{a}$ & $5.22 \pm 0.28 \mathrm{~b}$ \\
& Biofertilizer & $26.7 \pm 0.9 \mathrm{a}$ & $4.8 \pm 0.1 \mathrm{a}$ & $5.11 \pm 0.19 \mathrm{a}$ & $6.46 \pm 0.23 \mathrm{a}$ \\
Mung bean (MM) & Control & $19.3 \pm 1.2 \mathrm{~b}$ & $5.4 \pm 0.1 \mathrm{a}$ & $4.44 \pm 0.31 \mathrm{a}$ & $4.67 \pm 0.49 \mathrm{~b}$ \\
& Biofertilizer & $25.3 \pm 2.1 \mathrm{a}$ & $5.0 \pm 0.4 \mathrm{a}$ & $4.75 \pm 0.18 \mathrm{a}$ & $5.94 \pm 0.27 \mathrm{a}$ \\
Cowpea (JP) & Control & $11.7 \pm 1.2 \mathrm{a}$ & $6.4 \pm 0.4 \mathrm{a}$ & $7.48 \pm 0.62 \mathrm{a}$ & $5.58 \pm 0.55 \mathrm{a}$ \\
& Biofertilizer & $13.3 \pm 1.2 \mathrm{a}$ & $6.4 \pm 0.3 \mathrm{a}$ & $7.49 \pm 0.42 \mathrm{a}$ & $6.37 \pm 0.24 \mathrm{a}$ \\
Cowpea (MM) & Control & $16.0 \pm 2.9 \mathrm{a}$ & $5.7 \pm 0.5 \mathrm{a}$ & $7.69 \pm 0.39 \mathrm{a}$ & $6.90 \pm 0.96 \mathrm{a}$ \\
& Biofertilizer & $17.7 \pm 1.7 \mathrm{a}$ & $5.9 \pm 0.5 \mathrm{a}$ & $7.64 \pm 0.73 \mathrm{a}$ & $7.87 \pm 0.81 \mathrm{a}$ \\
Soybean (JP) & Control & $42.3 \pm 1.9 \mathrm{~b}$ & $1.9 \pm 0.0 \mathrm{a}$ & $18.47 \pm 1.42 \mathrm{a}$ & $14.68 \pm 1.55 \mathrm{~b}$ \\
& Biofertilizer & $53.0 \pm 5.1 \mathrm{a}$ & $1.9 \pm 0.1 \mathrm{a}$ & $18.11 \pm 0.33 \mathrm{a}$ & $18.03 \pm 1.01 \mathrm{a}$ \\
Soybean (MM) & Control & $53.3 \pm 5.2 \mathrm{~b}$ & $1.9 \pm 0.1 \mathrm{a}$ & $17.10 \pm 0.14 \mathrm{a}$ & $16.87 \pm 0.50 \mathrm{~b}$ \\
& Biofertilizer & $67.3 \pm 2.1 \mathrm{a}$ & $1.9 \pm 0.0 \mathrm{a}$ & $17.06 \pm 0.33 \mathrm{a}$ & $21.49 \pm 0.68 \mathrm{a}$ \\
\hline
\end{tabular}

For each cultivar, mean values with the same letters in each column are not significantly different at $p<0.05$ (Tukey's test). JP: Japanese variety, MM: Myanmar variety, V3: three unfolded trifoliate leaves, R2: full bloom stage, R3.5: early pod-fill stage. 


\section{Discussion}

The bacteria that live in the rhizosphere and induce beneficial effects on plant growth are referred to as plant growth-promoting rhizobacteria (PGPR) [34]. PGPR belong to several genera, including Azotobacter, Bacillus, Rhizobium, Bradyrhizobium, and Streptomyces [35]. Some PGPR are used as biofertilizers [36]. Bradyrhizobium are nitrogen fixers due to their potential to fix nitrogen in soybean. Streptomyces are promising biocontrol agents because of their potential to produce a wide range of secondary substances such as vitamins, alkaloids, plant growth factors, enzymes, and enzyme inhibitors [37,38]. Streptomyces are plant growth-promoting bacteria because of their potential to promote the growth of crop plants [39]. Therefore, there is interest in evaluating the symbiotic effectiveness of biofertilizers produced from Bradyrhizobium strains and Streptomyces on leguminous crops.

In our study, biofertilizer application increased the shoot growth of komatsuna, root growth of wheat, maize, sweet pea, and common bean, and shoot and root growth of mung bean, cowpea, and soybean grown in vermiculite (Tables 1 and 2). Moreover, biofertilizer application increased the shoot growth of mung bean and soybean from early (V3 and R2) to later (R3.5 and R8) growth stages and that of cowpea cultivated in soil at early growth stages (V3 and R2) (Table 4). Meguro et al. [40] reported that the endophytic strain Streptomyces spp. MBR-52 enhanced the emergence and elongation of plant adventitious roots. Soe and Yamakawa [41] found that inoculation of S. griseoflavus P4 enhanced the growth of soybean, sweet pea, rice, spinach, maize, and wheat, perhaps via the production of IAA. Soe and Yamakawa [41] revealed that with longer incubation times, S. griseoflavus P4 secreted more IAA, ranging from 0.8 to $2.8 \mu \mathrm{g} \mathrm{mL}-1$. In our study, the $S$. griseoflavus $\mathrm{P} 4$ in the biofertilizer promoted growth because IAA-producing microorganisms stimulate root elongation and enhance plant growth [42].

The plants with biofertilizer produced from Bradyrhizobium strains plus S. griseoflavus P4 promoted nodulation ability (Tables 5 and 6). Soe et al. [43] found that the co-inoculation of P4 with B. yuanmingense MAS34 significantly improved the nodule dry weight of soybean. The combined use of bradyrhizobial strains and S. griseoflavus P4 increased nodulation [44].

In this study, the application of biofertilizer produced from Bradyrhizobium and S. griseoflavus P4 increased $\mathrm{N}$ fixation by soybean and mung bean compared with the control (Tables 5 and 6). Our study supports previous findings that co-inoculation of bradyrhizobial strains and S. griseoflavus $\mathrm{P} 4$ increased nitrogen fixation by soybean [45-47].

The application of the biofertilizer produced from Bradyrhizobium and S. griseoflavus P4 increased the N, P, and K uptakes of soybean and mung bean compared with the control (Tables 7-9). These results support our previous finding that inoculation of Bradyrhizobium with P4 significantly increased the N, P, and K uptakes of soybean compared with an un-inoculated control [48,49]. Beneficial microorganisms can keep the soil environment rich in all kinds of micro- and macronutrients via nitrogen fixation, phosphate and potassium solubilization or mineralization, the release of plant growth regulators, the production of antibiotics, and the biodegradation of organic matter in the soil [18].

Soe et al. [50] reported that the combined use of Bradyrhizobium strains and S. griseoflavus P4 had a significant effect on the number of pods per plant in Yezin-12 and CM-6 compared with the uninoculated control. This was in line with our findings that the use of a biofertilizer produced from effective Bradyrhizobium strains and S. griseoflavus P4 significantly increased the number of pods per pot in both soybean and mung bean (Table 10). Consequently, biofertilizer application increased the seed yield of mung bean and soybean. Our study supports the findings of Soe and Yamakawa [51] showing that co-inoculation of bradyrhizobial strains and P4 increased the seed yield of soybean. Moreover, the seed yield of mung bean significantly improved with the application of biofertilizer produced from Bradyrhizobium and S. griseoflavus P4.

In this study, we observed significant increases in plant growth, nodulation, and nitrogen fixation in mung bean and soybean. Our experimental results confirmed the findings of Akarapisan et al. [52] that $S$. griseoflavus $\mathrm{P} 4$ is an effective endophytic actinomycete that can be used together with selected 
root nodule bacterial strains for the production of economically important leguminous crops by enhancing symbiotic nitrogen fixation, increasing nodulation, and promoting plant growth.

\section{Conclusions}

In conclusion, the biofertilizer was effective in mung bean, cowpea, and soybean regardless of $\mathrm{N}$ application. Significant increases in plant growth, nodulation, nitrogen fixation, NPK uptake, and seed yield were seen in mung bean and soybean. Therefore, the Myanmar biofertilizer produced from Bradyrhizobium strains with $S$. griseoflavus $\mathrm{P} 4$ should be useful not only for soybean production but also for mung bean production.

Author Contributions: Conceptualization, A.Z.H. and T.Y.; methodology and investigation, A.Z.H., S.M.M., K.M.S., K.M., data organization and formal analysis, A.Z.H.; writing-original draft preparation, A.Z.H.; writing-review and editing, S.M.M., K.M.S., K.M.; supervision, T.Y.; and All authors read and approved the manuscript.

Funding: This research and APC were supported by the Ministry of Education, Culture, Sports, Science, and Technology Grant Number: [130287].

Acknowledgments: We are thankful to Ministry of Education, Culture, Sports, Sciences and Technology (MEXT) of Japan for their financial support of the present study.

Conflicts of Interest: There is no financial support or relationships that may pose conflict of interest.

\section{References}

1. Department of Agriculture at a Glance, Department of Agricultural Planning; Ministry of Agriculture, Livestock and Irrigation: Nay Pyi Taw, Myanmar, 2016.

2. Graham, P.H.; Vance, C.P. Legumes. Importance and constraints to greater use. Plant Physiol. 2003, 131, 872-877. [CrossRef] [PubMed]

3. Jensen, E.S.; Hauggaard-Nielsen, H. How can increase use of biological $\mathrm{N}_{2}$ fixation in agriculture benefit the environment? Plant Soil 2003, 252, 177-186. [CrossRef]

4. Roychowdhury, R.; Banerjee, U.; Sofkova, S.; Tah, J. Organic farming for crop improvement and sustainable agriculture in the Era of climate change. OnLine J. Biol. Sci. 2013, 13, 50-65. [CrossRef]

5. Sawada, H.; Kuykendall, L.D.; Young, J.M. Changing concepts in the systematics of bacterial nitrogen-fixing legume symbiosis. J. Gen. Appl. Microbiol. 2003, 49, 155-179. [CrossRef] [PubMed]

6. Bottomley, P.J.; Myrold, D.D. Biological N inputs. In Soil Microbiology, Ecology, and Biochemistry; Academic Press: Oxford, UK, 2007; p. 377.

7. Tena, W.; Wolde-Meskel, E.; Walley, F. Symbiotic efficiency of native and exotic Rhizobium strains nodulating lentil (Lens culinaris Medik.) in soils of southern Ethiopia. Agronomy 2016, 6, 11. [CrossRef]

8. Franche, C.; Lindstrom, K.; Elmerich, C. Nitrogen-fixing bacteria associated with leguminous and non-leguminous plants. Plant Soil 2009, 321, 35-59. [CrossRef]

9. Stacey, G.; Libault, M.; Brechenmacher, L.; Wan, J.; May, G.D. Genetics and functional genomics of legume nodulation. Curr. Opin. Plant Biol. 2006, 9, 110-121. [CrossRef]

10. Hungria, M.; Vargas, M.A.T. Environmental factors impacting $\mathrm{N}_{2}$ fixation in legumes grown in the tropics, with an emphasis on Brazil. Field Crop Res. 2000, 65, 151-164. [CrossRef]

11. Bhullar, G.S.; Bhullar, N.K. Agricultural Sustainablilty: Progress and Prospects in Crop Research; Swiss Federal Institute of Technology: Zurich, Switzerland, 2013.

12. Dacko, M.; Zajac, T.; Synowiec, A.; Oleksy, A.; Klimek-Kopyra, A.; Kulig, B. New approach to determine biological and environmental factorsinfluencing mass of a single pea (Pisum sativum L.) seed in Silesiaregion in Poland using a CART model. Eur. J. Agron. 2016, 74, 29-37. [CrossRef]

13. Baligar, V.C.; Fageria, N.K.; He, Z.L. Nutrient use efficiency in plants. Commun. Soil Sci. Plant Anal. 2001, 32, 921-950. [CrossRef]

14. He, Z.L.; Yang, X.E.; Stoffella, P.J. Trace elements in agroecosystems and impacts on the environment. J. Trace Elem. Med. Biol. 2005, 19, 125-140. [CrossRef] 
15. Than, H.; Aung, N.N.; Kyi, P.P. Response of rhizobial peat inoculants on five important legumes. In Proceedings of the Myanmar Agricultural Science Research Division, 18th Congress, Yezin, Myanmar, 1987; pp. 1-12.

16. Alves, B.J.R.; Boddey, R.M.; Urquiaga, S. The success of BNF in soybean in Brazil. Plant Soil 2004, 252, 1-9. [CrossRef]

17. Souza, R.; Ambrosini, A.; Passaglia, L.M.P. Plant growth-promoting bacteria as inoculants in agricultural soils. Genet. Mol. Biol. 2015, 38, 401-419. [CrossRef]

18. Sinha, R.K.; Valani, D.; Chauhan, K.; Agarwal, S. Embarking on a second green revolution for sustainable agriculture by vermiculture biotechnology using earthworms: Reviving the dreams of Sir Charles Darwin. J. Agric. Technol. Sustain. Dev. 2010, 2, 113-128.

19. Vessey, J.K. Plant growth promoting rhizobacteria as bio-fertilizers. Plant Soil 2003, 255, 571-586. [CrossRef]

20. Mazid, M.; Khan, T.A. Future of bio-fertilizers in Indian agriculture: An overview. Int. J. Agric. Food Res. 2015, 3, 10-23. [CrossRef]

21. DAR. Rhizobium biofertilizer. In The result of Research of Agricultural Research; Department of Agricultural Research: Yezin, Myanmar, 2004; pp. 114-118.

22. Than, M.M.; San, K.K.; Thein, M.M. Evaluation of effective rhizobial strains for commercial legume inoculants. J. Agric. For. Livest. Fish. Sci. 2006, 6, 264-280.

23. Topre, S.D.; Panikar, S.S.; Mahajani, S.U. Biofertilizer: A novel approach for agriculture. J. Agric. Biotechnol. Sustain. Dev. 2011, 3, 205-208.

24. Herridge, D.; Maw, J.B.; Thein, M.M.; Rupela, O.P.; Boonkerd, N.; Thao, T.Y.; Deaker, R.; Hartley, E.; Gemell, G. Expanding production and use of legume inoculants in Myanmar and Vietnam. In Proceedings of the 14th Agronomy Conference, Adelaide, Australia, September 2008.

25. Htwe, A.Z.; Moh, S.M.; Moe, K.; Yamakawa, T. Biofertilizer prodcution and application for enhancing plant growth, nodulation, nitrogen fixation, nutrient uptake and seed yield of soybeans. Agronomy 2019. Submitted.

26. Nakano, Y.; Yamakawa, T.; Ikeda, M.; Ishizuka, J. Nodulation of Rj-soybean varieties with Rhizobium fredii USDA193 under limited supply of nutrients. Soil Sci. Plant Nutr. 1997, 43, 929-932. [CrossRef]

27. Haider, J.; Hussam, A.K.M.A.; Ikeda, M.; Yamakawa, T.; Ishizuka, J. Effects of nitrate application on growth, nodulation and nitrogen fixation of nitrate-tolerant mutant soybean. Soil Sci. Plant Nutr. 1991, 37, 521-529. [CrossRef]

28. Ohyama, T.; Ito, M.; Kobayashi, K.; Araki, S.; Yasuyoshi, S.; Sasaki, O.; Yamazaki, T.; Soyama, K.; Tanemura, R.; Mizuno, Y.; et al. Analytical procedures of N, P, K contents in plant and manure materials using $\mathrm{H}_{2} \mathrm{SO}_{4}-\mathrm{H}_{2} \mathrm{O}_{2}$ Kjeldahl digestion method. Jpn. Bull. Facul. Agric. Niigata Univ. 1991, 43, 110-120.

29. Cataldo, D.A.; Schrader, L.E.; Youngs, V.L. Analysis by digestion and colrimetric assay of total nitrogen in plant tissues high in nitrate. Crop Sci. 1974, 14, 854-856. [CrossRef]

30. Murphy, J.; Riley, J.P. A modified single solution for the determination of phosphate in natural waters. Anal. Chim. Acta 1962, 27, 31-36. [CrossRef]

31. Sahrawat, K.L. Nitrogen availability indexes for submerged rice soils. Adv. Agron. 1983, 36, 415-451.

32. Truog, E. The determination of the readily available phosphorus in soils. Agron. J. 1930, $22,874-882$. [CrossRef]

33. Muramoto, J.; Goto, I.; Ninaki, M. Rapid analysis of exchangeable cation and cation exchange capacity (CEC) of soils by shaking extraction method. Soil Sci. Plant Nutr. 1992, 63, 210-215.

34. Schroth, M.N.; Hancock, J.G. Selected topics in biological control. Ann. Rev. Microbiol. 1981, 35, $453-476$. [CrossRef]

35. Weller, D.M. Biological control of soil borne plant pathogens in the rhizosphere with bacteria. Ann. Rev. Phytopathol. 1988, 26, 379-407. [CrossRef]

36. Bharathi, V.; Sudhakar, R.; Parimala, K.; Reddy, V.A. Evaluation of bioagents and biofertilizers for the management of seed and seedling diseases of Sesamum indicum (Sesame). Int. J. Pytopathol. 2013, 2, 179-186.

37. Lehr, N.A.; Schrey, S.D.; Hampp, R.; Tarkka, M.T. Root inoculation with a forest soil. Streptomycete leads to locally and systemically increased resistance against phytopathogens in Norway Spruce. New Phytol. 2008, 177, 965-976. [CrossRef] [PubMed]

38. Prabavathy, V.R.; Mathivanan, N.; Murugesan, K. Control of blast and sheath blight disease of rice using antifungal metabolites produced by Streptomyces sp. PM5. Biolog. Control 2006, 39, 313-319. [CrossRef] 
39. Compant, S.; Duffy, B.; Nowak, J.; Clement, C.; Barka, E.A. Use of plant growth-promoting bacteria for biocontrol of plant diseases: Principles, mechanisms of action, and future prospects. Appl. Environ. Microbiol. 2005, 71, 4951-4959. [CrossRef] [PubMed]

40. Meguro, A.; Ohmura, Y.; Hasegawa, S.; Shinizu, M.; Nishimura, T.; Kunoh, H. An endophytic actinomycete, Streptomyces sp. MBR-52, that accelerates emergence and elongation of plant adventitious roots. Actinomycetologica 2006, 20, 1-9. [CrossRef]

41. Soe, K.M.; Yamakawa, T. Evaluating the effects of Streptomyces griseoflavus P4 on dry weight of different crops and examine phytohormones activity in term of indole acdic acid (IAA) production. Myanmar Agric. Res. J. 2018, 4, 165-171.

42. Patten, C.L.; Glick, B.R. Role of Pseudomonas putida indoleacetic acid in development of the host plant root system. Appl. Environ. Microbiol. 2002, 68, 3795-3801. [CrossRef]

43. Soe, K.M.; Yamakawa, T. Evaluation of effective Myanmar Bradyrhizobium strains isolated from Myanmar soybean and effects of coinoculation with Streptomyces griseoflavus P4 for nitrogen fixation. Soil Sci. Plant Nutr. 2013, 59, 361-370. [CrossRef]

44. Soe, K.M.; Bhromsiri, A.; Karladee, D.; Yamakawa, T. Effects of endophytic actinomycetes and Bradyrhizobium japonicum strains on growth, nodulation, nitrogen fixation and seed weight of different soybean varieties. Soil Sci. Plant Nutr. 2012, 58, 319-325. [CrossRef]

45. Soe, K.M.; Bhromsiri, A.; Karladee, D. Effect of selected endophytic actinomycetes (Steptomyces sp.) and bradyrhizobia from Myanmar on growth, nodulation, nitrogen fixation and yield of different soybean varieties. CMU J. Nat. Sci. 2010, 9, 95-109.

46. Htwe, A.Z.; Yamakawa, T. Enhanced plant growth and/or nitrogen fixation by leguminous and non-leguminous crops after single or dual inoculation of Streptomyces griseoflavus P4 with Bradyhizobium strains. Afr. J. Microbiol. Res. 2015, 9, 2337-2344.

47. Htwe, A.Z.; Yamakawa, T. Low-density co-inoculation with Bradyrhizobium japonicum SAY3-7 and Streptomyces griseoflavus P4 promotes plant growth and nitrogen fixation in soybean cultivars. Am. J. Plant Sci. 2016, 7, 1652-1661. [CrossRef]

48. Htwe, A.Z.; Moh, S.M.; Moe, K.; Yamakawa, T. Effects of co-inoculation of Bradyrhizobium japonicum SAY3-7 and Streptomyces griseoflavus P4 on plant growth, nodulation, nitrogen fixation, nutrient uptake, and yield of soybean in a field condition. Soil Sci. Plant Nutr. 2018, 64, 222-229. [CrossRef]

49. Htwe, A.Z.; Moh, S.M.; Moe, K.; Yamakawa, T. Effects of co-inoculation of Bradyrhizobium elkanii BLY3-8 and Streptomyces griseoflavus P4 on Rj4 soybean varieties. Soil Sci. Plant Nutr. 2018, 64, 449-454. [CrossRef]

50. Soe, K.M.; Myint, S.S.; Win, M.M.; Aung, T.T.; San, K.K.; Myint, S.S. Co-inoculation of Myanmar Bradyrhizobium yuanmingense MAS34 and Streptomyces griseoflavus P4 inoculants to improve plant Growth, seed Yield of soybean cultivars and soil fertility improvement. Myanmar Agric. Res. J. 2018, 4, 154-164.

51. Soe, K.M.; Yamakawa, T. Low-density co-inoculation of Myanmar Bradyrhizobium yuanmingense MAS34 and Streptomyces griseoflavus $\mathrm{P} 4$ to enhance symbiosis and seed yield in soybean varieties. Am. J. Plant Sci. 2013, 4, 1879-1892. [CrossRef]

52. Akarapisan, A.; Bhromsiri, A.; Sangmanee, P. Selection of suitable isolates of endophytic actinomycetes and rhizobia for improvement of $\mathrm{N}_{2}$ fixation and disease control of various Pisum sativum on the highland area. As. J. Food Ag-Ind. 2008, 297, 297-306.

(C) 2019 by the authors. Licensee MDPI, Basel, Switzerland. This article is an open access article distributed under the terms and conditions of the Creative Commons Attribution (CC BY) license (http:/ / creativecommons.org/licenses/by/4.0/). 